1 .研究課題名：シグナル伝達の時空間動態を光て制御して光て解析する

- 生理活性を光て制御するケージド化合物の開発と产の応用 -

\title{
2.研究者氏名：古田 寿昭
}

\section{3. 研究のねらい:}

複雑で高度に秩序化された生体内反応を制御するために、生体はさまざまな情報をやに取り儿 ている。これらはいくかのシグナル伝達系て制御されているが、より深理解するためには、シ グナリングに関与する分子が、いつ、どこで、どのように働 功を明らかにする必要がある。しかし 従来の方法論だけでは、この素過程を生理的条件に近い時間および空間分解能て解析すること は困難である。乥こで、ケージド化合物を利用して細胞内あるいは細胞間での情報のやり取りを 高い時空間分解能て操作する手法の開発を目的として研究を行つた。

\section{4.研究結果 :}

ケージト化合物とは、光分解性の保護基で生理活性分子を保護し、一時的に关の活性を失わせ た分子のことである。光を照射することで、瞬時に元の生理活性分子を出現させることが出来る。 シグナル分子が機能発現する時期と場所を、光を照射する時期と場所で制御することが可能にな り、照射光量で発現する量を調節することも原理的には可能となる。本研究では、我々のグルー プて開発した光分解性保護基である Bhc 基 6-ブロモ- 7- ヒドロキシクマリン- 4 イルメチル基)を 用いて、さまざまな情報分子のケージト化合物を合成することから始めた。

(1)神経伝達物質およびセカンドメッゼンジャーのケージド化合物の設計 合成

神経伝達物質のケージド化合物として、グルタミン酸、グリシン、アスパラギン酸、GABA および D-セリンのケージト化合物の合成に成功した。これらの化学的な性質を調べて、ケージト化合物と して適当かどうか検討した結果、いずれの化合物も1光子励起の光感受性の面では申し分ない 性質を持っていた。カルボキシル基側にケージを導入したものについては、暗所での安定性が光 れほど高〈ない 半減期 12-30 時間)とい㵍題点も明らかとなったが、Bhc 基がアミノ酸全般をケ ージト化合物に変換できることが分かったので これをぺプチトに拡張し、RGD アルギニンーグリ シンーアスパラギン酸) モチーフを持つペプチドのケージト化合物を合成した。合成したケージド RGD ペプチドが、光照射によってほぼ定量的に元の RGD ペプチドを放出することと、HL- 60 細胞 前骨髄性白血病細胞)のアポトーシスを光制御できることが確認出来た。例えば、細胞接着に伴 うインテグリンを介したシグナル伝達の分子機構を調べるツールとしての応用が期待できる。また、 合成したケージド神経伝達物質を脳スライスサンプルに適用して、電気生理学的手法と組み合わ せることで、神経細胞間の情報伝達を光照射によって擬似的に再現して解析することも可能とな る。

続いて、セカンドメッセンジャーのケージド化合物として、cAMP、cGMP、ジアシルグリセロールお よびアラキドン酸のケージド化合物を合成した。合成法の最適化、光反応性の検討およひ酵素反 応の光制御能等を明らかにし、さらに、cAMP に関しては、樣々な細胞内への導入法に対応でき るように、膜透過性のものと水溶性が高いものを合成した。膜透過性誘導体はメダカの色素胞へ 導入し、CAMP が関わるシグナル伝達系を光照射によって繰り返し制御できることを確認した。ま た、水溶性誘導体をパッチピペットによって単離嗅細胞に導入し、匂い感知後のシグナル伝達を 光照射によって再現できることも確認できた。しかし、これらのケージド化合物に2光子励起を適 
用し、高い空間分解能で反応を制御することも目標としていたが、弚ちらはほとんと手付かずとし て残ってしまった。今後の課題としたい。

(2)任意の遺伝子の機能を光て制御する方法の開発

生体における情報のやりとりの主役分子はタンパク質である。Bhc ケージド化合物の応用の1 つとして、遺伝子の機能を制御することを検討した。サイクリックヌクレオチトのケージト化合物合 成用に開発した Bhc-ジアゾを用いることで、mRNA のケージト化合物 Bhc-mRNA)を合成するこ とかできた。Bhc-mRNA をゼブラフィツシュ初期胚に導入することで、任意の mRNA の発現時期お よひ部位特異的な過乗発現をin vivo で行うことにも成功した。同樣な考え方でタンパク質レベル での機能発現の光制御も可能となる。さらに、ケージド化合物の化学を拡張することで、任意の 遺伝子およびタンパク質の機能阻害を行うことも可能になるであろう。今後のさらなる発展への足 掛かりができたと考えている。

(3)新しいケージの開発

Bhc 基は、従来のものに比べて1光子励起の効率が遥かに高いとい沜徵を持つが、まだ万能 ではない。乥こで，これとは異なる性質を持ち、相補的に用いる事かできるようなケージの開発を 目指し、Anthraquinon- 2-ylmethoxycarbonyl (Aqmoc) 基の開発に成功した。これは、水酸基やア ミ/基を持つ生理活性物質のケージト化合物合成への応用が可能で、特徵としては、1光子励起 の効率が比較的高いことと、ケージ解除後の副生成物が紫外領域の光を吸収しないことがあげ られる。今後は、さらに異なる性質を持つケージ 例えば、暗所での安定性が高いもの、可視光で ケージ解除できるものなど)の開発も進めてい《必要がある。

\section{5.自己評価 :}

当初の計画では、ケージド化合物の化学を活用して生きた細胞の機能を制御することと、新し い蛍光プローブを開発して可視化解析することを目指した。3年間で各種のケージド化合物を開 発することに成功し、さらに、遺伝子の機能制御という、さきかけ参加以前では思いもよらなかっ た方向に研究を展開することが出来た。しかし 合成したケージド化合物を用いた機能制御は相 変わらず共同研究頼みであること、成果の大部分を期間内に論文としてまとめられなかったこと、 また、可視化解析に関しては全〈手を付けることが出来なかったこと等、数多〈の反省点も残して しまつた。

\section{6 .研究総括の見解 :}

生理活性物質の活性部位を特異な化合物を結合してマスク ケージト化合物化)し、光の照射に より瞬時に光の活性部位を露出する技法の研究を行なっている。光分解性保護基として既に6-ブ ロモ- 7- ヒドロキシクマリン- 4 イルメチル基 Bhc 基)を開発し、神経伝達物質としてのアミノ酸類や ペプチ蘱に応用し、白血病細胞におけるアポトーシスの光制御に成功した。また、本領域の他 研究者の注目を引き、cAMP などのケージト化合物を合成し、メダ力の色素胞で cAMP 関与の信 号伝達系を任意に操作することを示した。さらにメッゼンジャ一RNA をケージト化し、ゼブラフイシュ の初期胚中で、任意の時点に翻訳を行わせることも可能とした。炎の他、樣々な可能性を示唆し ており、新しい研究技法として注目される。

\section{7 .主な論文等 :}

1. Mizuta, H., Watanabe, S., Sakauchi, H., Nishiyama, K., Furuta, T., Kobayashi, Y., and Iwamura, 
M. (2002). Design, Synthesis, photochemical properties and cytotoxic activities of watersoluble caged leucyl- leucine methyl esters that control apoptosis of immune cells. Bioorg. Med. Chem. 10, 675- 683.

2. Furuta, T., Hirayama, Y., and Iwamura, M. (2001). Anthraquinone- 2-ylmethoxycarbonyl (Aqmoc): a new photovhemically removable protecting group for alcohols. Org. Lett. 3 , 1809- 1812.

3. Ando, H., Furuta, T., Tsien, R. Y., and Okamoto, H. (2001). Photo- mediated gene activation using caged RNA/DNA in zebrafish embryos. Nature Genetics 28, 317- 325.

その他

招待講演 国内 1件 